\title{
Biomass and density of native stands of Durvillaea potatorum (southern bull-kelp) in south eastern Australia
}

\author{
Anthony C. Cheshire*, Neil D. Hallam \\ Botany Department, Monash University, Clayton, Victoria 3168, Australia
}

\begin{abstract}
To date, there have been no large-scale surveys of the density or biomass of Durvillaea stands in south eastern Australia. This paper presents data from the first such survey and provides evidence to suggest that Durvillaea potatorum stands support an exceptionally high biomass relative to many other marine and terrestrial ecosystems. The differences in density and biomass have been reviewed for populations of $D$. potatorum harvested throughout its distribution in south eastern Australia. Densities vary between 0.8 and 23.5 plants $\mathrm{m}^{-2}$, biomasses range from 4 to $108 \mathrm{~kg} \mathrm{~m}^{-2}$. These results are comparable to, but in the upper range of, the values observed for other species of brown algae. The level of concordance of $D$. potatorum populations to the $3 / 2$ power law has been assessed. $D$. potatorum populations breach the boundary condition implied by the $3 / 2$ power law when $\log (\mathrm{k})=4.3$; if this law does hold for $D$. potatorum populations the appropriate $\log (\mathrm{k})$ value is likely to be around 5.0 , suggesting a carrying capacity in these systems of up to $100 \mathrm{~kg} \mathrm{~m}^{-2}$. This is ca 5 times higher than that reported for any other plant ecosystem.
\end{abstract}

\section{INTRODUCTION}

Along the exposed rocky coasts of the colder-temperate to sub-antarctic regions of the Southern Hemisphere the genus Durvillaea (Bory) is a dominant and visually impressive member of the intertidal to shallow sub-tidal flora. Plants within the genus may attain lengths in excess of $10 \mathrm{~m}$ with wet weights exceeding $75 \mathrm{~kg}$; this places them amongst the most massive of all algae (Cheshire 1985, Hallam unpubl.). Throughout south eastern Australia the endemic representative of this genus, Durvillaea potatorum (La Billardiere) Areschoug, often forms extensive, near monospecific beds over rocky substrata on exposed coasts.

Durvillaea potatorum lives and grows within an environment characterised by high surge and surf. An understanding of the biology of an organism which grows in such extreme conditions provides a useful starting point from which to compare and contrast other ecosystems. Differences in density and biomass of kelp and fucoid stands have been studied by a number of authors (Table 1); the studies demonstrate that differences in density and biomass relate both to species

\footnotetext{
- Present address: Australian Institute of Marine Science,
} PMB No. 3, Townsville MC, Queensland 4810, Australia composition of the stands and to interaction of the given species with its environment, principally in relation to water depth and exposure to wave force.

In this paper we present the results of a large-scale survey of biomass and density of Durvillaea potatorum stands throughout the species distribution area in south eastern Australia. The only other studies on density and biomass of Durvillaea stands are those of South \& Hay $(1974,1979)$ on $D$. antarctica (Chamisso) Hariot and $D$. willana Lindauer in New Zealand. In addition, I we examined whether the $3 / 2$ power law (Yoda et al. 1963) could be used to predict the 'average weight/ density' relations of $D$. potatorum stands.

\section{MATERIALS AND METHODS}

Thirty-three populations from 15 sites throughout south eastern Australia were selected for study (Fig. 1). At each site areas within Durvillaea potatorum stands were cleared of all plants; those collected were classified as either juvenile (stipe circumference less than $40 \mathrm{~mm}$ ) or adult (stipe circumference greater than or equal to $40 \mathrm{~mm}$; see Cheshire \& Hallam 1988 for justification). A total of 1782 plants were collected.

At each site, the total biomass of both adult and 
Table 1 Comparisons of density and biomass from a variety of kelp and fucoid stands (Durvillaea anarctica, Eklonia radiata, Laminaria digitata, L. Iongicruris, L. ochroleuca, L. hypobrea, Agarum cribosum, Saccorhiza polyschides) throughout the world

\begin{tabular}{|c|c|c|c|}
\hline Species & $\begin{array}{l}\text { Density } \\
\left(n \mathrm{~m}^{-2}\right)\end{array}$ & $\begin{array}{l}\text { Biomass } \\
\left(\mathrm{kg} \mathrm{m}^{-2}\right)\end{array}$ & $\begin{array}{c}\text { Source, } \\
\text { environment, } \\
\text { sampling }\end{array}$ \\
\hline D. antarctica & $10-30$ & $15-20$ & (South \& Hay 1974, 1979); range of exposures \\
\hline E. radiata & $15-30$ & $6-19$ & (Kirkman 1984); adult (stage 3) plants \\
\hline $\begin{array}{l}\text { Fucus \& Ascophyllum } \\
\text { L. digitata \& L. longicruris } \\
\text { L. longicruris } \\
\text { L. longicruris \& A. cribrosum } \\
\text { Macrocystis spp. }\end{array}$ & & $\begin{array}{c}10.7 \\
16 \\
11.5 \\
4.9 \\
22.0 \\
95-606\end{array}$ & $\begin{array}{l}\text { California } \\
\text { Indian Ocean }\end{array}$ \\
\hline Mixed fucoid stands & & $8-32$ & (Topinka et al. 1981) \\
\hline L. hypoborea & & $<13$ & (Norton et al. 1977); range of depths \\
\hline L. pallida & $1-5$ & $0.3-0.8^{\mathrm{a}}$ & (Velimirov et al. 1977); range of depths \\
\hline L. ochroleuca \& S. polyschides & & $0.1-2.1^{\mathrm{a}}$ & (John 1971); range of exposures \\
\hline L. ochroleuca & $0.2-0.8$ & $0.1^{1}$ & (Drew 1974) \\
\hline L. hypoborea & $10-62$ & $8-37$ & (Jupp \& Drew 1974); range of depths \\
\hline
\end{tabular}

juvenile plants and the numbers of plants in each category (adult or juvenile) were determined. In addition, site data were recorded which detailed the area harvested, the depth of the harvest site (below LWST) and a score for relative exposure, exposed (1) or protected (0), based on whether offshore reefs or breakwaters existed or whether embayment of the sites provided protection from direct wave force. Average wave heights at each site over a 5 yr period were derived from sea state data provided by the Australian Bureau of Meteorology.

Results were analysed using canonical correlation analyses and Mann Whitney $U$ tests available within the SPSS package (Nie et al. 1975) and linear regression analyses from the BMDP package (Dixon \& Brown 1979).

\section{RESULTS}

\section{Density and biomass}

The standing crop varied between 4 and $108 \mathrm{~kg} \mathrm{~m}^{-2}$ (fresh weight) with an average of $22.5 \mathrm{~kg} \mathrm{~m}^{-2}$. Adult densities varied between 0.8 and 23.5 plants $\mathrm{m}^{-2}$ with an average of 4.9 plants $\mathrm{m}^{-2}$. Within regions, a linear relation exists between density and biomass of constituent populations; in some cases however this is poorly defined (Table 2).

There is an overall trend for a change from high density and low biomass in areas of low exposure to low density and high biomass in areas of high exposure. This trend was highlighted by a canonical correlation analysis between the independent variables depth, average wave height, and exposure, and the dependant variables biomass and density. The analysis identified 2 canonical vectors (Table 3); the first is a density/biomass vector which identified a difference between populations with a low density and a high biomass compared to those with a high density and a low biomass, the second is an environmental vector which defines an exposure

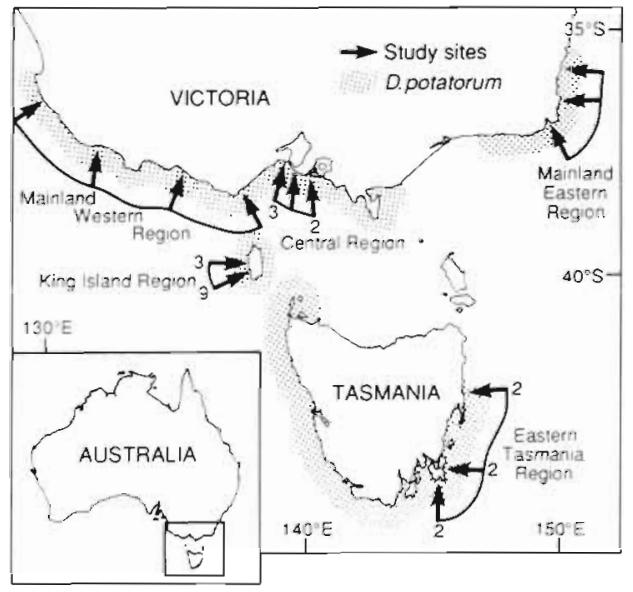

Fig. 1 Distribution of Durvillaea potatorum in Australia Throughout its range $D$. potatorum is restricted to areas with high wave exposure and stable rocky substrata Arrows: study sites with number of areas sampled where $>1$; regional groupings of study sites are indicated 
Table 2. Regression equations and statistics for density/biomass relationships within regions

\begin{tabular}{|c|c|c|c|c|}
\hline Regions & $n$ & Slope & $r^{2}$ & $p$ \\
\hline ALL & 31 & 3.0 & 0.6 & $\cdots$ \\
\hline Mainland Central & 6 & 2.6 & 0.8 & $\cdots$ \\
\hline King Island & 12 & 6.5 & 0.8 & $\cdots$ \\
\hline Mainland Western & 4 & 2.7 & 1.0 & $\cdots$ \\
\hline Eastern Tasmania & 6 & 2.5 & 0.6 & $\cdot$ \\
\hline Mainland Eastern & 3 & 1.6 & 1.0 & $\cdots$ \\
\hline \multicolumn{5}{|c|}{$\begin{array}{l}\text { Statistics relate to a regression forced through the origin } \\
\text { rather than a line of 'best fit' for given values (logically a } \\
\text { density of } 0 \text { plants } \mathrm{m}^{-2} \text { must have a biomass of } 0 \mathrm{~kg} \mathrm{~m}^{-2} \text { ). } \\
\text { p } p<0.05, \cdots p<0.01 \text {. Slopes differ significantly between } \\
\text { groups }(p<0.01 \text { ) }\end{array}$} \\
\hline
\end{tabular}

gradient. The correlation between these 2 vectors was significant ( $p=0.04, I=0.61$ ) explaining $12.7 \%$ of the variance in the dependant variables.

There is a significant change in density/biomass associated with a change in morphology. The change from a high density, low biomass population to a low density, high biomass population is correlated with an increase in mean plant length and a reduction in mean stipe length ( $p=0.02, r=0.87$ ). Table 3 details the results of a canonical correlation analysis which quantifies these changes. Whilst morphology has been defined as the independent variable suite in this analysis, neither of these variable suites are appropriately

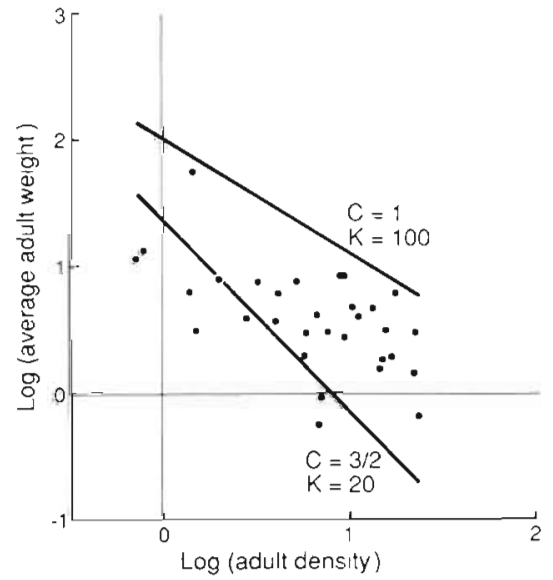

Fig. 2. Log/log plot of adult density (plants $\mathrm{m}^{-2}$ ) vs adult average weight $\left(\mathrm{kg}\right.$ plant $\left.{ }^{-1}\right)$. Most populations exceed the boundary state defined by $\mathrm{k}=20 \mathrm{~kg} \mathrm{~m}^{-2}, \mathrm{C}=3 / 2(\mathrm{k}=20000$ $\mathrm{g} \mathrm{m}^{-2}$, therefore $\log (\mathrm{k})=4.3$ ). An alternative boundary has been suggested at $\mathrm{k}=100 \mathrm{~kg} \mathrm{~m}^{-2}, \mathrm{C}=1\left(\mathrm{k}=100000 \mathrm{~g} \mathrm{~m}^{-2}\right.$ therefore $\log (k)=5.0$ )

defined as independent as both are mediated by exposure. The change in biomass/density associated with changes in morphology explains $51 \%$ of the variance in the biomass/density data set.

There is no significant correlation between biomass/ density and latitude/longitude.

Both density and biomass are significantly higher in shallow-water sites (depth less than or equal to $1 \mathrm{~m}$ ) when compared to deeper-water sites. The groups show a significant difference in density (Mann-Whitney $U$ statistic, $T=3.16, p<0.005$ ); the difference in

Table 3. Results from canonical correlation analyses

\begin{tabular}{|c|c|c|c|c|c|}
\hline \multirow{2}{*}{$\begin{array}{l}\text { Canonical } \\
\text { correlation }\end{array}$} & \multirow{2}{*}{$\begin{array}{c}\text { F-value } \\
2.46\end{array}$} & \multirow{2}{*}{ Sig of $F$} & \multicolumn{3}{|c|}{ Standardized canonical coefficients: } \\
\hline & & & Dependant variables: & $\begin{array}{l}\text { Density } \\
\text { Biomass }\end{array}$ & $\begin{array}{r}-0.98 \\
0.91\end{array}$ \\
\hline & & & Covariates: & $\begin{array}{l}\text { Depth } \\
\text { Ave. wave height } \\
\text { Exposure }\end{array}$ & $\begin{array}{r}0.66 \\
-0.51 \\
-0.72\end{array}$ \\
\hline \multirow[t]{2}{*}{0.87} & 2.44 & 0.017 & Dependant variables: & $\begin{array}{l}\text { Density } \\
\text { Biomass }\end{array}$ & $\begin{array}{r}-1.02 \\
0.87\end{array}$ \\
\hline & & & Covariates: & $\begin{array}{l}\text { Palm thickness } \\
\text { Maximum width } \\
\text { Maximum length } \\
\text { Number secondary } \\
\text { Stipes } \\
\text { Stipe circumference } \\
\text { Stipe length } \\
\text { Number of perforations } \\
\text { Wet weight }\end{array}$ & $\begin{array}{r}0.25 \\
0.14 \\
0.51 \\
\\
-0.02 \\
0.25 \\
-0.35 \\
0.36 \\
0.01\end{array}$ \\
\hline
\end{tabular}


biomass is significant but only just so $(\mathrm{T}=2.05,0.05>$ $p>0.02$ ). These results are in marked contrast to the results from the canonical correlation analysis which described an overall increase in standing crop, but a reduction in density, associated with increasing depth (Table 3). This apparent contradiction will be pursued in the following discussion.

\section{The $3 / 2$ power law}

Of the 31 populations analysed, 23 exceed the boundary state defined by the $3 / 2$ power law (Yoda et al. 1963) when $\log (\mathrm{k})=4.3$ (Fig. 2). It seems likely that if stands of Durvillaea potatorum thin according to the power law then the appropriate boundary condition is defined by $\log (k) \simeq 5.0$. Such a condition implies a biomass in self thinning populations of around $100 \mathrm{~kg}$ $\mathrm{m}^{-2}$ (equivalent to the maximum values found in this study) which is 5 times the generalised maximum proposed (Cousens \& Hutchings 1982, Hutchings 1983).

\section{DISCUSSION}

\section{Density and biomass}

The average standing crop of $22.5 \mathrm{~kg} \mathrm{~m}^{-2}$ (fresh weight) for Durvillaea potatorum is higher than the $15.1 \mathrm{~kg} \mathrm{~m}^{-2}$ for $D$. antarctica (South \& Hay 1974, 1979, Hay 1977), and is in the upper range of those for other large brown algae which range from 6 to $37 \mathrm{~kg} \mathrm{~m}^{-2}$ (Table 1). The extreme high value of $108 \mathrm{~kg} \mathrm{~m}^{-2}$ is higher than that reported for any population of $D$. antarctica $\left(20.4 \mathrm{~kg} \mathrm{~m}^{-2}\right.$, South \& Hay 1974, 1979, Hay 1977) and compares to that of 95 to $606 \mathrm{~kg} \mathrm{~m}^{-2}$ for Macrocystis spp. in the Indian Ocean (Mann 1973).

Average density (4.9 adult-plants $\mathrm{m}^{-2}$ ) is generally lower than those reported for other kelps but compares to those for the adult density of Laminaria pallida ranging from 1.0 to 4.7 plants $\mathrm{m}^{-2}$ (Velimirov et al. 1977). Hay (1977) gives densities for Durvillaea antarctica of 2.6 to 12.9 plants $\mathrm{m}^{-2}$ and $D$. willana of 3.1 to 17.5 plants $\mathrm{m}^{-2}$ (for plants exceeding $1 \mathrm{~m}$ in length) Most other studies quote total plant density, not adult density.

A general relationship of increased density correlated with increased biomass is seen both in the existence of a significant correlation between biomass and density in all 6 regions (Table 2) and is further supported by the results of the Mann Whitney U analysis (testing the difference between the shallow and deeper water populations). A conformance to a linear relationship between density and biomass implies that differences in biomass (between populations within regions) are purely a function of changes in density; the average weight of plants remains constant.

This general trend of high densities correlated with high biomasses is not unique to Durvillaea potatorum; South \& Hay $(1974,1979)$ showed that both density and biomass of $D$. antarctica and $D$. willana populations increased with increasing turbulence. A re-examination of their data suggests that changes in biomass may be attributed primarily to increases in density with average plant weight remaining relatively constant. Similar results were obtained by Norton et al. (1977) for

Table 4. Model proposed to define trajectories and allowable states in the 'average weight/density' space

Hypothesis
$\begin{aligned} & \text { (1) Within any region average weight of } \\ & \text { plants does not vary significantly be- }\end{aligned}$
tween populations
weight of plants did not vary between
populations


Laminaria hypoborea and by Velimirov et al. (1977) for L. pallida.

The association of increased biomass with increased density is less clearly resolved when viewed across the distribution as a whole. The canonical correlation analysis (biomass and density vs average wave height, exposure and depth) indicated quite a different trend. On a distribution wide basis there is a trend for an increase in density and a decrease in biomass as the wave energy of the environment changes from low to high. This correlation contradicts the other results and suggests that whilst density is increased in higher energy environments this increase is not associated with an increase in biomass.

To account for the apparent difference between these 2 results we propose the model detailed in Table 4 ; with this model we can explain all of these results. Fig. 3 illustrates our data in context with some idealized density/biomass relationships developed within the confines of this model: it becomes clear that as more populations achieve the maximum biomass (defined by the boundary condition specified within the model), the relationship of decreased biomass relative to increased density will become more clearly defined. Within any given region the morphology is determined by the level of exposure to wave force, and this exposure defines a value for the average weight as discussed by Cheshire \& Hallam (1988). Given this value for average weight, the biomass attainable by any population is then a function of density and may exhibit a linear response of increased biomass correlated with increased density up to, but not exceeding, the boundary state shown in Fig. 3. Hypothesis 3 of this model invokes a concordance to the $3 / 2$ power law (this is discussed in the next sec-

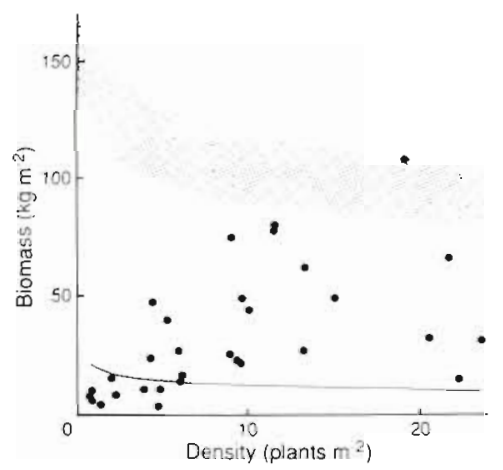

Fig. 3. Effect of hypotheses in Table 4 on population biomass/ density states. Limiting boundary has been drawn assuming the limiting function is of the form:

$$
\text { Biomass }=\mathrm{k} \cdot \frac{1}{\mathrm{D}^{\mathrm{C}-1}} \equiv \log (\mathrm{w})=\log (\mathrm{k})-\mathrm{C} \cdot \log (\mathrm{D}) \text {. }
$$

Lower line: boundary defined when $\mathrm{k}=20 \mathrm{~kg} \mathrm{~m}^{-2}$ and $\mathrm{C}=$ $3 / 2$. Upper shaded area: region in which boundary should be defined based on our study of Durvillaea potatorum with $\mathrm{k} \simeq$ $100 \mathrm{~kg} \mathrm{~m}^{-2}(\log (\mathrm{k})=5.0)$ tion). Our data suggest that this law is applicable to the density/biomass states of Durvillaea beds.

Plants from high density populations have longer stipes, a morphological feature which is reminiscent of the etiolation response in higher plants. It is probable that plants growing in high density environments are light limited: extension of the stipe pushes the lamina higher into the canopy and provides a competitive advantage over shorter stiped plants. The concomitant reduction in overall length associated with these high density stands is less easily explained however, most of these high density populations are intertidal: Cheshire \& Hallam (1988) showed that plants from intertidal sites have greatly reduced lengths due to the greater levels of erosion in this high turbulence environment.

The relation between density/biomass and average morphology of the adult plants in these populations prompts the question as to which is cause and which is effect. Is it a mutual feed back of one to the other? Alternatively, are they coincidentally related via a third factor? The answers to these questions are equivocal. Density and biomass are related to wave force but with a low correlation; they are not significantly related to locality. Morphology does have a strong relation to wave force (Cheshire \& Hallam 1988); alternatively the correlation between morphology and biomass may be coincidental due to the individual correlation of these factors to wave force.

\section{The 3/2 power law}

The $3 / 2$ power law defines a relationship between the average weight ( $\mathrm{g} \mathrm{plant}^{-1}$ ) and density (plants $\mathrm{m}^{-2}$ ) in any even-aged, monospecific stand such that $\log (\mathrm{W})=\log (\mathrm{k})-\mathrm{C} \cdot \log (\mathrm{D})$ (where $\mathrm{W}=$ average plant weight; $\mathrm{k}=$ constant related to the carrying capacity of the stand; $\mathrm{C}=$ constant defining the slope of the thinning curve, i.e. the rate at which density reduces as plant weight increases; and $D=$ density of plants in the population). Thus, in a population undergoing density dependent thinning, a straight line of slope $-C$ exists between the 2 population characters, plant density and average plant weight. Invariably $C=3 / 2$ and this has resulted in the relationship being termed the $3 / 2$ power law (White 1985). The value for $\log (\mathrm{k})$ is an estimate of the carrying capacity of the system in $\mathrm{g} \mathrm{m}^{-2}$ (Hutchings 1983). If $\log (k)=4.3$, which has been suggested as a generalized maximum for most systems (Cousens \& Hutchings 1982, Hutchings 1983), then a maximum biomass of approximately $20 \mathrm{~kg} \mathrm{~m}^{-2}$ is predicted.

A theoretical maximum biomass of $20 \mathrm{~kg} \mathrm{~m}^{-2}$ conforms well with the overall average standing crop of 22 $\mathrm{kg} \mathrm{m}^{-2}$ found for Durvillaea potatorum in this study and the range noted for other species (Table 1); $D$. 
antarctica 9.9 to $20.4 \mathrm{~kg} \mathrm{~m}^{-2}$ with an average of $15.1 \mathrm{~kg}$ $\mathrm{m}^{-2}$ (South \& Hay 1974, 1979), Eklonia radiata 6 to 19 $\mathrm{kg} \mathrm{m}^{-2}$ (Kirkman 1984) and Macrocystis spp. $22.0 \mathrm{~kg}$ $\mathrm{m}^{-2}$ (Mann 1973). While the average conforms to this value for $\log (\mathrm{k})$ it does not relate to the range of biomasses found for $D$. potatorum populations by our study (up to $108 \mathrm{~kg} \mathrm{~m}^{-2}$ )

The reasons for this exceptionally high biomass can only be speculated upon and a number of factors need to be considered. The environment in which Durvillaea potatorum grows is characterised by strong surge and surf with a constant turnover of water. Associated with this turnover is the rapid removal of wastes, a near constant supply of metabolic substrates (dissolved nutrients and gases) and a buffer to changes in temperature, providing an environment which is optimal for the maintenance of a high biomass. In addition to this. the 'flicker effect' - produced by the continuous change in the orientation of the lamina with respect to incident light - may well provide an enhancement to the level of carbon assimilation. Living within the wave break zone, the plant is constantly being turned over as each wave firstly breaks in and then surges back out. Carbon assimilation may be enhanced by short intervals of light and dark ( $1 \mathrm{~s}$ or less) which allow the dark reaction to run to completion and thus restore the photosynthetic apparatus before the start of each light period (Steeman-Nielsen 1957). This means that rapid periodic pulses of light on the lamina are more effective than constant illumination at any given light intensity.

Problems exist when species with differing life histories are compared in terms of the $3 / 2$ power law. Plants which produce seeds may store their reproductive potential in a seed bank; when conditions permit, rapid regeneration of the population may occur through germination of this seed bank - stands of this type are often evenly aged. Conversely, in an alga (especially one with an oogamous life cycle) which does not produce a seed stage, reproductive potential must be stored in juvenile plants which may remain relatively small in size until a gap in the canopy allows rapid growth (a situation similar to the one in many rainforests). This has been observed for Eklonia radiata (Kirkman 1984) and was suggested for Durvillaea antarctica (Hay 1977).

A strategy in which populations store their reproductive potential in germlings or juveniles will result in populations with an inflated density relative to those that store reproductive potential in a seed bank (seeds are not counted as individuals in density/average weight analysis for seed producing plants). Populations with a large number of juvenile plants tend to have a right skew in the distribution of individual plant weights; this skew causes problems in the estimation of a true or representative average weight. Our study assessed both adult density/adult average weight and overall density/overall average weight for the populations. In both cases the density/average weight status of certain populations breaches the $-3 / 2$ thinning boundary defined when $\log (k)=4.3$; in order to accommodate all populations we need to define a boundary at or around $\log (\mathrm{k})=5.0$ (Fig, 2).

If Durvillaea potatorum stands are not in breach of the boundary condition $[\log (\mathrm{k})=5.0]$ this suggests further support for the Cousens \& Hutchings (1982) proposal that marine systems are not fundamentally different from terrestrial systems. It should be noted however that our study looked at a series of spatially and temporally separated populations, not at an individual population through time. Thus, whilst the populations described may not breach a boundary condition, it cannot be said that these results demonstrate that the thinning of dense populations occurs according to the power law in $D$. potatorum stands

Acknowledgements. We thank the Kelp Harvesters Association of King Island, the Tasmanian Fisheries Department, Alginate Industries (Scotland), the Victorian Institute of Marine Science and the Australian Marine Science and Technology Commission (AMSTAC) all of whom have provided funds for this research. In addition we acknowledge $\mathrm{Mr} \mathrm{W}$. Rolley, Ms M. Meinderts and Ms M. Klemm for assistance with field collections. A. Cheshire undertook this work with the aid of a Commonwealth Government Research Studentship provided by AMSTAC. Drs Edward Drew and Clive Wilkinson both provided valuable criticism of the manuscript, and the Australian Institute of Marine Science provided facilities and assistance in the preparation of the manuscript.

\section{LITERATURE CITED}

Cheshire, A. C. (1985). The biology of Durvillaea potatorum (La Billardiere) Areschoug. Ph.D. thesis, Botany Department, Monash University, Victoria, Australja

Cheshire, A. C., Hallam, N. D. (1988). Differences in the morphology of the Southern Bull-kel.p (Durvillaea potatorum, Durvilleales, Phaeophyta) from different habitats around King Island (Bass Strait, Australia). Botanica mar. 31. 139-148

Cousens, R., Hutchings, M. J. (1982). The relationship between density and mean frond weight in monospecific seaweed stands. Nature, Lond. 301. 240-241

Dixon, W. J., Brown, M. B. (1979). Biomedical computer programs P-series. University of California Press

Drew, E. A. (1974). An ecological study of Laminaria ochroleuca Pyl growing below 50 metres in the Straits of Messina. J exp. mar Biol. Ecol. 15: 11-24

Hay, C. (1977). A biological study of Durvillaea antarctica (Chamisso) Hariot and D. willana Lindauer in New Zealand. Ph. D. thesis, Zoology Department, University of Cantebury, New Zealand

Hutchings, M. (1983). Ecology's law in search of a theory. New Scient. 16th June 1983. 765-767

John, D. M. (1971). The distribution and net productivity of sublittoral populations of attached macrophytic algae in an estuary on the Atlantic coast of Spain. Mar. Biol. 11(1): 90-97 
Jupp, B. P., Drew, E. A. (1974). Studies on the growth of Laminaria hyperborea (Gunn.) Fosl. I. Biomass and productivity. J. exp. mar. Biol. Ecol. 15: 185-196

Kirkman, H. (1984). Standing stock and production of Eklonia radiata (C. Ag.) J. Argadh. J. exp. mar Biol. Ecol. 76: $119-130$

Mann, K. H. (1973). Seaweeds: their productivity and strategy of growth. Science 182: 4116

Nie, N. H., Hull, C. H., Jenkins, J. G., Stienbrenner, D. H., Bent, D. H. (1975). SPSS: Statistical package for the social sciences, 2nd edn. McGraw-Hill, New York

Norton, T. A., Hiscock, K., Kitching, J. A. (1977). The ecology of Lough lne XX. The Laminaria forest at Carrigathorna. J. Ecol. 65: 919-941

Schiel, D. R., Choat, J. H. (1980). Effects of density on monospecific stands of marine algae. Nature, Lond. 285: $324-326$

South, G. R., Hay, C. (1974). Variation in morphology and standing crop in New Zealand D. antarctica (Chamisso) Hariot in relation to exposure and latitude. Proc. Internat. Seaweed Symp. 8: 489498
South, G. R., Hay, C. (1979). Influence of wave action and latitude on morphology and standing crop of New Zealand Durvillaea antarctica (Chamisso) Hariot (Phaeophyta, Durvilleales). J. R. Soc. New Zealand 9(3): 289-296

Steeman-Nielsen, E. (1957). The chlorophyll content and the light utilization in communities of plankton algae and terrestrial higher plants. Physiol. Plant. 10: 1009-1021

Topinka, L., Tucker, L., Korjeff, W (1981). The distribution of fucoid macroalgal biomass along Central Coastal Maine. Botanica mar 24: 311-319

Velimirov, B., Field, J. G., Griffith, C. L., Zoutendyk, P. P. (1977). The ecology of kelp bed communities in the Benguela upwelling system. Helgoländer Meeresunters. 30: $495-518$

White, J. (1985). The thinning rule and its application to mixtures of plant populations. In: White J. (ed.) Studies on plant demography. Academic Press, New York, p 291-309

Yoda, K., Kua, T., Ogawa, H., Hozumi, K. (1963). Self-thinning in overcrowded pure stands under cultivated and natural conditions. J. Biol. Osaka City Univ. 14: 97-129

This article was submitted to the editor; it was accepted for printing on July 19, 1988 